\title{
Cooperative effects of field traffic and organic matter treatments on some compaction-related soil properties
}

\author{
Metin Mujdeci $^{1}$, Ahmet Ali Isildar ${ }^{1}$, Veli Uygur ${ }^{1}$, Pelin Alaboz ${ }^{1}$, Husnu Unlu ${ }^{2}$, and Huseyin Senol ${ }^{1}$ \\ ${ }^{1}$ Suleyman Demirel University, Faculty of Agriculture, Department of Soil Science and Plant Nutrition, Isparta, Turkey \\ ${ }^{2}$ Suleyman Demirel University, Faculty of Agriculture, Department of Horticultural Sciences, Isparta, Turkey \\ Correspondence to: Metin Mujdeci (metinmujdeci@sdu.edu.tr)
}

Received: 1 June 2016 - Discussion started: 9 August 2016

Revised: 15 November 2016 - Accepted: 8 January 2017 - Published: 20 February 2017

\begin{abstract}
Soil compaction is a common problem of mineral soils under conventional tillage practices. Organic matter addition is an efficient way of reducing the effects of field traffic in soil compaction. The aim of this study was to investigate the effects of number of tractor passes (one, three, and five) on depth-dependent $(0-10$ and $10-20 \mathrm{~cm})$ penetration resistance, bulk density, and porosity of clay-textured soil (Typic Xerofluvent) under organic vegetable cultivation practices in the 2010-2013 growing seasons. Fields were treated with farmyard manure (FYM, $35 \mathrm{tha}^{-1}$ ), green manure (GM; common vetch, Vicia sativa L.), and conventional tillage (CT). The number of tractor passes resulted in increases in bulk density and penetration resistance $(\mathrm{CT}>\mathrm{GM}>\mathrm{FYM})$, whereas the volume of total and macropores decreased. The maximum penetration resistance $(3.60 \mathrm{MPa})$ was recorded in the CT treatment with five passes at $0-10 \mathrm{~cm}$ depth, whereas the minimum (1.64 MPa) was observed for the FYM treatment with one pass at $10-20 \mathrm{~cm}$ depth. The highest bulk density was determined as $1.61 \mathrm{~g} \mathrm{~cm}^{-3}$ for the CT treatment with five passes at $10-20 \mathrm{~cm}$ depth; the smallest value was $1.25 \mathrm{~g} \mathrm{~cm}^{-3}$ in the FYM treatment with only one pass at 0 $10 \mathrm{~cm}$ depth. The highest total and macropore volumes were determined as 0.53 and $0.16 \mathrm{~cm}^{3} \mathrm{~cm}^{-3}$ respectively at 0 $10 \mathrm{~cm}$ depth for the FYM treatment with one pass. The volume of micropores $\left(0.38 \mathrm{~cm}^{3} \mathrm{~cm}^{-3}\right)$ was higher at $0-10 \mathrm{~cm}$ depth for the FYM treatment with three passes. It can be concluded that organic pre-composted organic amendment rather than green manure is likely to be more efficient in mitigating compaction problems in soil.
\end{abstract}

\section{Introduction}

Agricultural development resulted in the increase in the food supply for humankind, but it also resulted in the increase in soil and water losses, reduction of the vegetation cover, and degradation of the soil (Cerda, 2000). One of the consequences of agricultural use and abuse is the increase in soil compaction. Soil compaction, which can be defined as a soil degradation process in which an applied pressure to the soil causes soil grains to get closer together, resulting in reduction of porosity and pore volume ratio, is regarded as the most serious environmental problem in conventional agriculture (McGarry, 2003). Since farmers have difficulty locating and rationalising this type of degradation without making any measurements, this problem can be more deleterious in conventional agriculture. In addition, compaction-induced shallow plant rooting and poor plant growth reduce crop yield for deep rooting plants and vegetative cover, which protect soil from erosion (Ni et al., 2015; Ola et al., 2015; Shaw et al., 2016). Compaction can increase run-off from and erosion of sloping land or waterlogged soils in flatter food slopes, depending on reduced water infiltration through soil surface (Al-Dousari et al., 2000; USDA-NRCS, 2012; Pulido et al., 2016). Intensive agriculturally-related soil compaction may be regarded as one of the significant reasons for land degradation (Cerda, 2000; Barbero-Sierra et al., 2015; Wang et al., 2015; Yan et al., 2015) and the elevated risks concerned with food security, water scarcity, climate change, biodiversity loss, and health threats, which were pointed out as soilrelated challenges for a sustainable society (Keesstra et al., 2016). 
The most significant cause of soil compaction is field traffic. Meanwhile, the close relation between field traffic density and frequency and crop type should also be taken into account (De Oliveira et al., 2015; Gelaw et al., 2015). Thus, more than $80 \%$ of corn and soybean fields is under tyre pressure in a growth season (Erbach, 1986). In cereal cultivation, 90, 35, and $60 \%$ of fields are under wheel pressure during seed bed preparation, harvesting, and baling practices respectively (Munsuz, 1985). Soil aeration, infiltration, and hydraulic conductivity parameters of soils, which are closely related to differential porosity, show decreases related to increased field traffic (Seker and Isildar, 2000; Aksakal, 2004). In order to prevent such adverse effects, decreased field traffic along with optimum moisture content of tillage soil, and increase in the organic matter content of soil using farmyard manure, compost, green manure, etc. Stabilisation and fortification of soil aggregates using organic matter can increase compaction resistance of soils (Cochrane and Aylmore, 1994; Thomas et al., 1996; Aksakal et al., 2016) and enhance the compaction-related attributes such as bulk density, pore-size distribution, infiltration, etc., in soils (Sparovek et al., 1999; Carter, 2002; Aksakal et al., 2016). The changes in soil organic carbon stock under different management systems (Munoz et al., 2015) can also influence total soil quality in soils. For example, Parras-Alcantra et al. (2015) reported a higher organic-farming-induced stratification ratio deeper in the surface horizon compared to conventional agricultural systems. Gelaw et al. (2015) pointed out that managing soil differently affected the partition of organic matter in different aggregate sizes, which in turn influenced bulk density and water-stable aggregates. Although the specific effect of field traffic was not elucidated in these studies (Gelaw et al., 2015; Parras-Alcantra et al., 2015), the management systems are closely related to traffic density and soil physical attributes. The organic matter is relevant to soil behaviour, but it is also relevant at the atmospheric level and to the behaviour of the earth system since it can control the carbon cycle (Novara et al., 2013; Kaleeem Abbasi et al., 2015; Peng et al., 2015).

Keesstra et al. (2016) pointed out the significance of raising public and farmer awareness about key attributes of soil organic matter to perform and sustain ecosystem services. Similarly, many researchers reported that soil physical and chemical properties in terms of fertility and sustainability of agriculture may be enhanced, to a large extent, by regular organic matter application (Aggelides and Londra, 2000; Alagoz et al., 2006; Mamman et al., 2007; Celik et al., 2010; Gulser and Candemir, 2012). The above-mentioned literature points out that the nature and extent of compactioninduced soil degradation can be exaggerated by a lack of organic matter. Artificial loosening of soils by deep ripping is a commonly suggested practice for elimination of the deleterious effects of compaction, but its effect is not long-lasting (Hamza and Anderson, 2003, 2008; Arslan, 2006). Organic matter addition is a fast and efficient way of conditioning soil physical attributes, especially soils that develop in a xeric environment. Despite the fact that the effect of organic matter on soil fertility and soil properties has been frequently investigated, there is a lack of information about comparative effects of continuous application of farmyard manure and green manure on soil physical attributes of soils that develop in a xeric environment suffering from a lack of organic matter under organic vegetable farming. Therefore, the aim of this study was to investigate the effects of both annual addition of different organic matter (farmyard manure and green manure) and field traffic density on penetration resistance, bulk density, and porosity in clay-textured soil with low organic matter content after 4 consecutive years of organic vegetable cultivation.

\section{Materials and methods}

\subsection{Study area and experimental design}

This study was carried out on an experimental field of the Agricultural Research and Application Centre of Suleyman Demirel University from 2010 to 2013. Chemical and physical properties of the soil are given in Table 1 .

Organic vegetables were cultivated with farmyard manure (FYM), green manure (GM), and conventional tillage (CT) without any organic matter treatments. The field experiment was set up with a completely randomised design with three replications. FYM application was executed between 21 May and 7 June on $35 \mathrm{tha}^{-1}$ (FYM consist of $45 \%$ dry matter), and the FYM was thoroughly mixed into the soil surface layer $(10-15 \mathrm{~cm})$ using a rototiller. Common vetch (Vicia sativa L.) was sowed in the second week of March and allowed to grow until the flowering stage between 21 May and 7 June. It was then incorporated into the soil first by chisel (20-25 cm tillage depth) and followed by rototillers (10$15 \mathrm{~cm}$ tillage depth). Both GM and FYM treatments were performed at the same time. The field was tilled by means of disc-harrowing at 10-15 cm depth (16 September 2013), and the field was then sprinkler irrigated on 27 September 2013. In order to increase the susceptibility of soils to compaction, field traffic was simulated at a soil water content just below the field capacity $\left(0.23 \mathrm{~g} \mathrm{~g}^{-1}\right)$ on 5 November 2013 . A tractor (80-66 s Fiat, manufactured in 1998) with 85 horse power (HP) weighing $3460 \mathrm{~kg}$, including the operator, was used to resemble field traffic. Tractor passes (one, three, and five times) were performed at $5 \mathrm{~km} \mathrm{~h}^{-1}$ speed on the same track. One disturbed and three undisturbed soil cores per plot were taken from 0-10 and 10-20 cm depths before each tractor pass; only undisturbed core samples were taken after each treatment pass. Penetration resistance, which is an indication of soil compaction, was measured with a penetrometer (Eijkelkamp penetrograph) equipped with a $1 \mathrm{~cm}^{2}$ cone attachment. Penetration resistance was performed in 15 replications per treatment at $2 \mathrm{~m}$ intervals and $0-20 \mathrm{~cm}$ depth. The 
Table 1. Chemical and physical properties of experimental soil and FYM (Uzumcu, 2016).

\begin{tabular}{lrrrrrrrr}
\hline & $\begin{array}{r}\text { Clay } \\
\left(\mathrm{g} \mathrm{kg}^{-1}\right)\end{array}$ & $\begin{array}{r}\text { Silt } \\
\left(\mathrm{g} \mathrm{kg}^{-1}\right)\end{array}$ & $\begin{array}{r}\text { Sand } \\
\left(\mathrm{g} \mathrm{kg}^{-1}\right)\end{array}$ & $\begin{array}{r}\text { Texture } \\
\text { class }\end{array}$ & $\begin{array}{r}\text { Organic matter } \\
\left(\mathrm{g} \mathrm{kg}^{-1}\right)\end{array}$ & $\begin{array}{r}\mathrm{CaCO}_{3} \\
(\%)\end{array}$ & $\mathrm{pH}$ & $\begin{array}{r}\mathrm{EC} \\
\left(\mathrm{dS} \mathrm{m}^{-1}\right)\end{array}$ \\
\hline Soil & & & & & & & & \\
$0-10 \mathrm{~cm}$ & 425.1 & 394.5 & 180.4 & Clay & 15.5 & 24.1 & 7.44 & 0.34 \\
$10-20 \mathrm{~cm}$ & 412.9 & 399.9 & 187.2 & Clay & 15.6 & 24.2 & 7.38 & 0.38 \\
FYM & - & - & - & - & 451 & - & 7.70 & 3.58 \\
\hline
\end{tabular}

Table 2. Porosity, bulk density, and organic matter content of the plots before passing.

\begin{tabular}{lrrrrrr}
\hline Treatments & $\begin{array}{r}\text { Depth } \\
(\mathrm{cm})\end{array}$ & $\begin{array}{r}\text { Total } \\
\left(\mathrm{cm}^{3} \mathrm{~cm}^{-3}\right)\end{array}$ & $\begin{array}{r}\text { Macro } \\
\left(\mathrm{cm}^{3} \mathrm{~cm}^{-3}\right)\end{array}$ & $\begin{array}{r}\text { Micro } \\
\left(\mathrm{cm}^{3} \mathrm{~cm}^{-3}\right)\end{array}$ & $\begin{array}{r}\text { Bulk } \\
\left(\mathrm{g} \mathrm{cm}^{-3}\right)\end{array}$ & $\begin{array}{r}\text { Organic } \\
\text { matter } \\
\left(\mathrm{g} \mathrm{kg}^{-1}\right)\end{array}$ \\
\hline CT & $0-10$ & 0.54 & 0.22 & 0.32 & 1.28 & 15.50 \\
& $10-20$ & 0.52 & 0.19 & 0.33 & 1.33 & 15.60 \\
\hline FYM & $0-10$ & 0.61 & 0.24 & 0.37 & 1.14 & 28.00 \\
& $10-20$ & 0.58 & 0.22 & 0.36 & 1.22 & 21.50 \\
\hline GM & $0-10$ & 0.59 & 0.23 & 0.36 & 1.20 & 17.40 \\
& $10-20$ & 0.55 & 0.20 & 0.35 & 1.25 & 18.30 \\
\hline
\end{tabular}

averages of resistance values obtained for the $0-10$ and 10$20 \mathrm{~cm}$ depths were evaluated. Physical and chemical properties of experimental soil, FYM, and plots before passing are given in Tables 1 and 2. Particle size distribution was determined by means of the Bouyoucos hydrometer method (Bouyoucos, 1962) and bulk density was determined using undisturbed soil cores (Blake and Hartge, 1986). For this analysis, soil cores were oven-dried, weighed, and then calculated by dividing the dry weight by the core volume. Total porosity was calculated from the ratio of water weight at saturation to total volume of a $100 \mathrm{~cm}^{3}$ undisturbed soil core (Danielson and Sutherland, 1986). Microporosity was accounted for as the volume of water at field capacity, measured by using a pressure membrane apparatus at $0.033 \mathrm{MPa}$ suction. Macroporosity was calculated from the difference between total porosity and microporosity (Danielson and Sutherland, 1986). A modified Walkley-Black wet oxidation method and dry ashing method (at $400^{\circ} \mathrm{C}$ for $16 \mathrm{~h}$ in an oven) were used for determining organic matter content of soil and FYM respectively (Burt, 2004). Soil pH and electrical conductivity (EC) were measured in a $1: 1$ soil-to-distilled water suspension, whereas $\mathrm{pH}$ and EC of FYM were determined in a $1: 2.5$ FYM-to-distilled water suspension (Burt, 2004). Carbonate equivalent was determined by a volumetric method using a Scheibler calcimeter (Kacar, 2009).

\subsection{Statistical analysis}

The data were subjected to descriptive analyses in order to check normal distribution. Aside from compaction data sets, all parameters measured showed typical normal distribution.
The compaction data were log-transformed before analysis of variance (ANOVA) using Minitab 16 statistical package programme (Minitab, 2010). The mean separation between the treatments was performed using a least significant difference (LSD) test at $95 \%$ confidence level.

\section{Results and discussion}

\subsection{Soil penetration resistance}

The application of FYM and GM for 4 subsequent years significantly reduced penetration resistance in both depths; however, the effect of FYM treatment was higher than GM treatment (Fig. 1, Table 3). This finding is in accordance with the previous studies (Celik et al., 2010; Gulser and Candemir, 2012; Xin et al., 2016). Incorporation of organic matter in clay-textured soils can strengthen the aggregates by weakening cohesion forces and interfering with the formation of crust and large aggregate (Aksakal et al., 2012). The larger amounts of added organic matter may mediate the formation of clay-organic matter complexes, which in fact reduces the penetration resistance on the one hand and protects organic matter against microbial decay on the other hand. In this respect, Blanco-Moure et al. (2016) investigated the effect of soil texture on carbon and organic matter distribution among different fractions under different tillage and management practices. They found that soil clay had a critical role in the chemical stabilisation of organic matter through clay-organic complexes in the soils. Czyz and Dexter (2016) pointed out the relation between the magnitude of clay-soil 

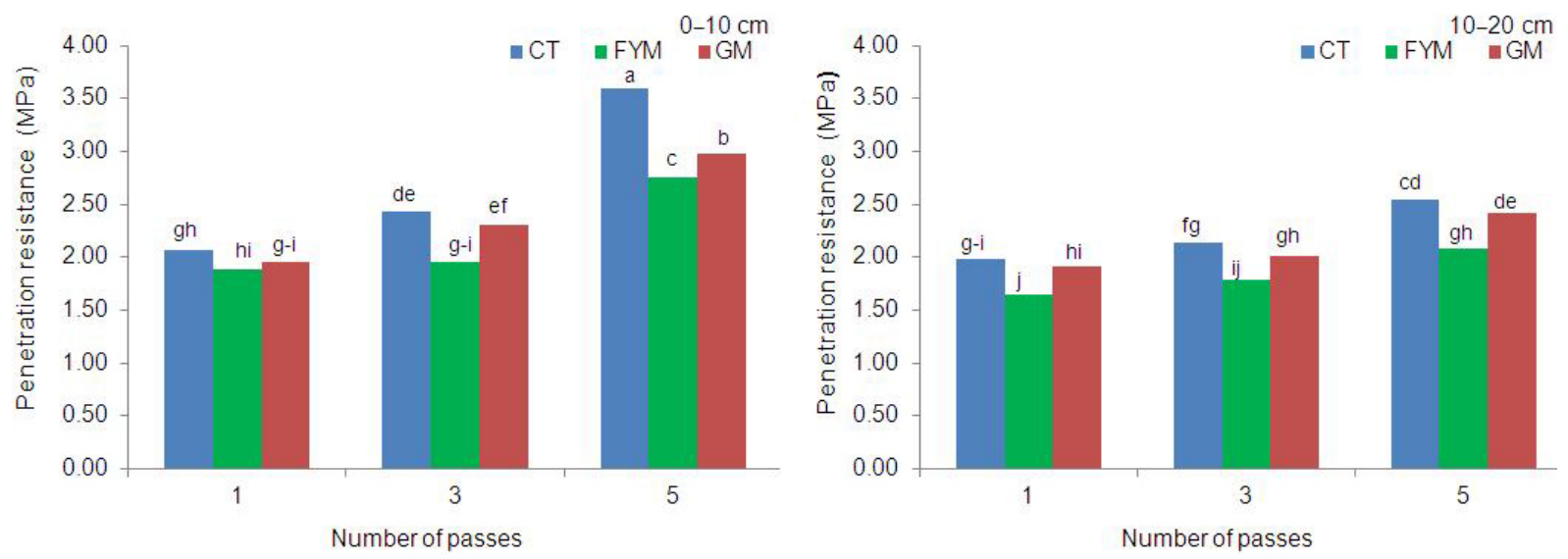

Figure 1. The effect of number of passes on penetration resistance at different depths (passing $\times$ depth $\times$ treatment). Different letters written above columns indicate the difference in the treatment means at $P<0.05$.

Table 3. Main effects of organic matter incorporation, depth, and number of passes on measured parameters.

\begin{tabular}{|c|c|c|c|c|c|}
\hline Treatments & $\begin{array}{r}\text { Penetration } \\
\text { resistance } \\
(\mathrm{MPa})\end{array}$ & $\begin{array}{r}\text { Bulk } \\
\text { density } \\
\left(\mathrm{g} \mathrm{cm}^{-3}\right)\end{array}$ & $\begin{array}{r}\text { Total } \\
\text { porosity } \\
\left(\mathrm{cm}^{3} \mathrm{~cm}^{-3}\right)\end{array}$ & $\begin{array}{r}\text { Micro } \\
\text { porosity } \\
\left(\mathrm{cm}^{3} \mathrm{~cm}^{-3}\right)\end{array}$ & $\begin{array}{r}\text { Macro } \\
\text { porosity } \\
\left(\mathrm{cm}^{3} \mathrm{~cm}^{-3}\right)\end{array}$ \\
\hline \multicolumn{6}{|c|}{ Organic matter } \\
\hline $\mathrm{CT}$ & $2.46 \mathrm{a}$ & $1.53 \mathrm{a}$ & $0.424 \mathrm{c}$ & $0.336 \mathrm{c}$ & $0.087 \mathrm{~b}$ \\
\hline FYM & $2.02 \mathrm{c}$ & $1.40 \mathrm{c}$ & $0.471 \mathrm{a}$ & $0.364 \mathrm{a}$ & $0.107 \mathrm{a}$ \\
\hline GM & $2.27 \mathrm{~b}$ & $1.47 \mathrm{~b}$ & $0.445 b$ & $0.354 b$ & $0.091 b$ \\
\hline LSD (0.05) & 0.045 & 0.016 & 0.0007 & 0.0033 & 0.0032 \\
\hline \multicolumn{6}{|l|}{ Depth } \\
\hline $0-10 \mathrm{~cm}$ & $2.44 \mathrm{a}$ & $1.43 \mathrm{~b}$ & $0.458 \mathrm{a}$ & $0.354 \mathrm{a}$ & $0.104 \mathrm{a}$ \\
\hline $10-20 \mathrm{~cm}$ & $2.06 \mathrm{~b}$ & $1.50 \mathrm{a}$ & $0.435 b$ & $0.349 \mathrm{~b}$ & $0.086 \mathrm{~b}$ \\
\hline LSD (0.05) & 0.037 & 0.013 & 0.0006 & 0.0027 & 0.0026 \\
\hline \multicolumn{6}{|l|}{ Passes } \\
\hline 1 & $1.91 \mathrm{c}$ & $1.38 \mathrm{c}$ & $0.480 \mathrm{a}$ & $0.349 \mathrm{~b}$ & $0.131 \mathrm{a}$ \\
\hline 3 & $2.10 \mathrm{~b}$ & $1.48 \mathrm{~b}$ & $0.441 b$ & $0.360 \mathrm{a}$ & $0.082 \mathrm{~b}$ \\
\hline 5 & $2.73 a$ & $1.54 \mathrm{a}$ & $0.418 \mathrm{c}$ & $0.345 \mathrm{c}$ & $0.073 \mathrm{c}$ \\
\hline LSD (0.05) & 0.045 & 0.016 & 0.0007 & 0.0033 & 0.0032 \\
\hline
\end{tabular}

complex and the porous and open nature of the structure. Thus, stable organic matter sources such as FYM resulted in desirable penetration resistance $(<2 \mathrm{MPa})$ for plant growth under changing field traffic.

The increasing number of passes, irrespective of the organic matter treatments and soil depth, increased soil compaction measured by penetration resistance (Table 3 ). The effect of field traffic on penetration resistance, as expected, was more negative in 0-10 cm depths (Table 3). Accordingly, Carman (1994) and Seker and Isildar (2000) determined a higher compaction ratio in the $0-10$ and $0-15 \mathrm{~cm}$ surface layers respectively. A penetration resistance value as high as
3.60 MPa in the surface layer caused by five passes in the control treatment (Fig. 1) with no organic matter may have significant inverse effects on infiltration, percolation, and run-off-induced erosion under intensive precipitation events in slopy lands (Kozlowski, 1999; Seker and Isildar, 2000). In this study, we also determined the well-known manner in which surface soil becomes more compact with field traffic, and the severity of the problem may be overcome by adding organic matter to soil or by adopting soil management systems with decreased annual traffic. The penetration resistance value at $10-20 \mathrm{~cm}$ depth obtained for CT and GM treatments after five passes was over $2 \mathrm{MPa}$, which is considered 

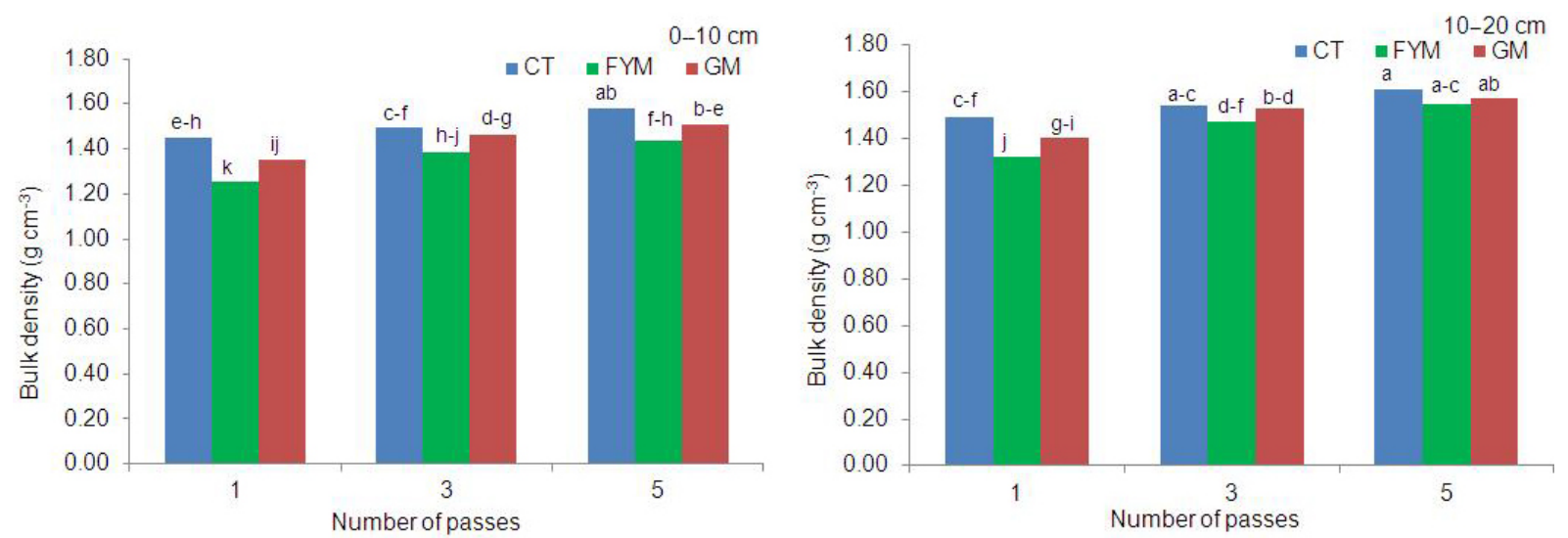

Figure 2. Number of passes and soil depth-dependent bulk density changes induced by organic matter treatments (passing $\times$ treatment, depth $\times$ treatment; $P<0.01$ ). Different letters written above the columns indicate the difference in the treatment means at $P<0.05$.
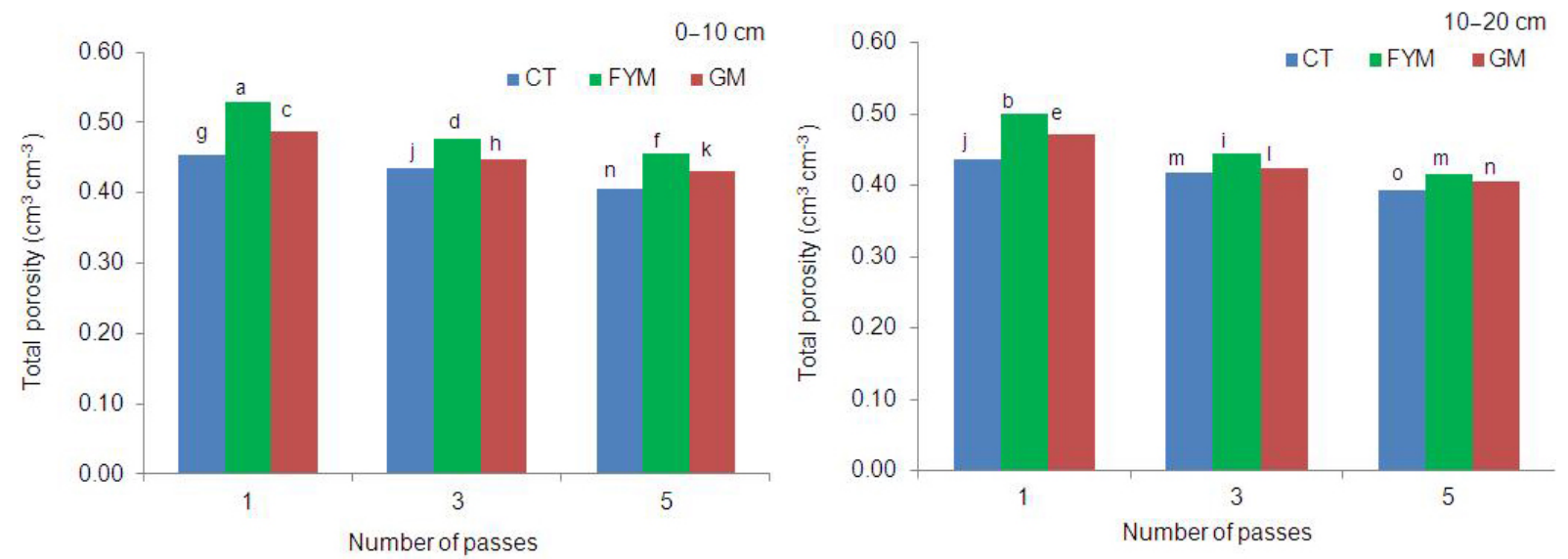

Figure 3. Number of passes and soil depth-dependent total porosity changes induced by organic matter treatments (passing $\times$ depth $\times$ treatment, $P<0.01$ ). Different letters written above the columns indicate the difference in the treatment means at $P<0.05$.

the limit value by the USDA (1993) as a critical physical quality parameter in conventional agricultural practices. This critical value can change depending on the soil tillage systems. For example, with minimum tillage practices where a chisel is used for soil tillage it is $3 \mathrm{MPa}$ and with no-till practices it is 3.5 MPa (De Moraes et al., 2014). The critical penetration resistance value that inhibits root development is accepted as $3 \mathrm{MPa}$ (Busscher and Sojka, 1987; Hakansson and Lipiec, 2000; Aksakal et al., 2011). Soil management systems can change soil organic carbon contents (Munoz-Rojas et al., 2015) and field traffic density, which ultimately degrade soil physical traits for optimal plant growth such as water-stable aggregates and bulk density (Gelaw et al., 2015). In fact, these tendencies of soil physical traits can lead to more compaction in both the surface and subsurface soil layers, as in our case.

\subsection{Bulk density}

The main effect of organic matter treatments on bulk density was statistically significant $(P<0.01)$. Both FYM and GM incorporation into soil were distinctly different than the control (Table 3). FYM amendment reduced the bulk density to as low as $1.40 \mathrm{~g} \mathrm{~cm}^{-3}$. Similar to our findings, decreases induced by adding organic matter (Haynes and Naudi, 1998; Chaudhari et al., 2013; Gulser and Candemir, 2012) and increases in bulk density related to field traffic (Seker and Isildar, 2000; Patel and Mani, 2011) have been frequently reported in the literature. The magnitude of the above-mentioned changes were depth dependent. In terms of plant growth, Aksakal et al. (2016) reported the enhancing effect on bulk density of increasing vermicompost treatment rate for three soils with differing clay content. In general, mixing of soil with less-dense organic material results in decreased particle density in soils amended with organic manures (Haynes and Naidu, 1998). However, their efficiency in 

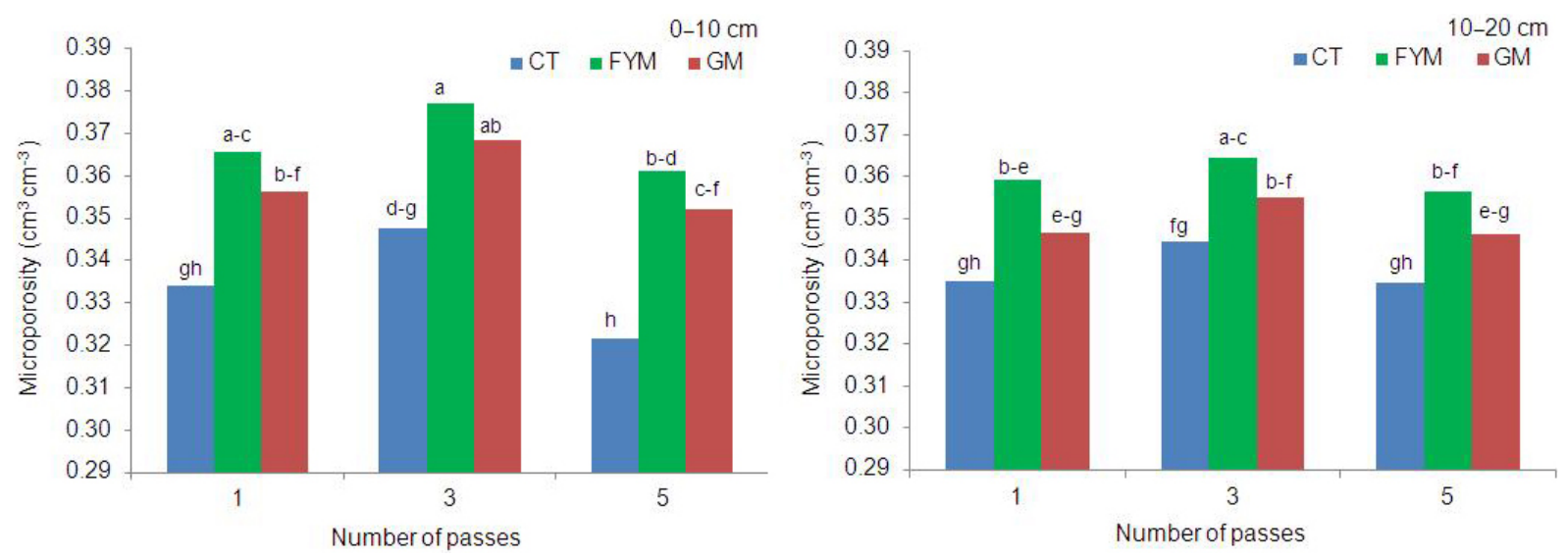

Figure 4. Number of passes and soil depth-dependent microporosity changes induced by organic matter treatments (passing $\times$ depth; $P<0.05$, depth $\times$ treatment; $P<0.01)$ Different letters written above the columns indicate the difference in the treatment means at $P<0.05$.
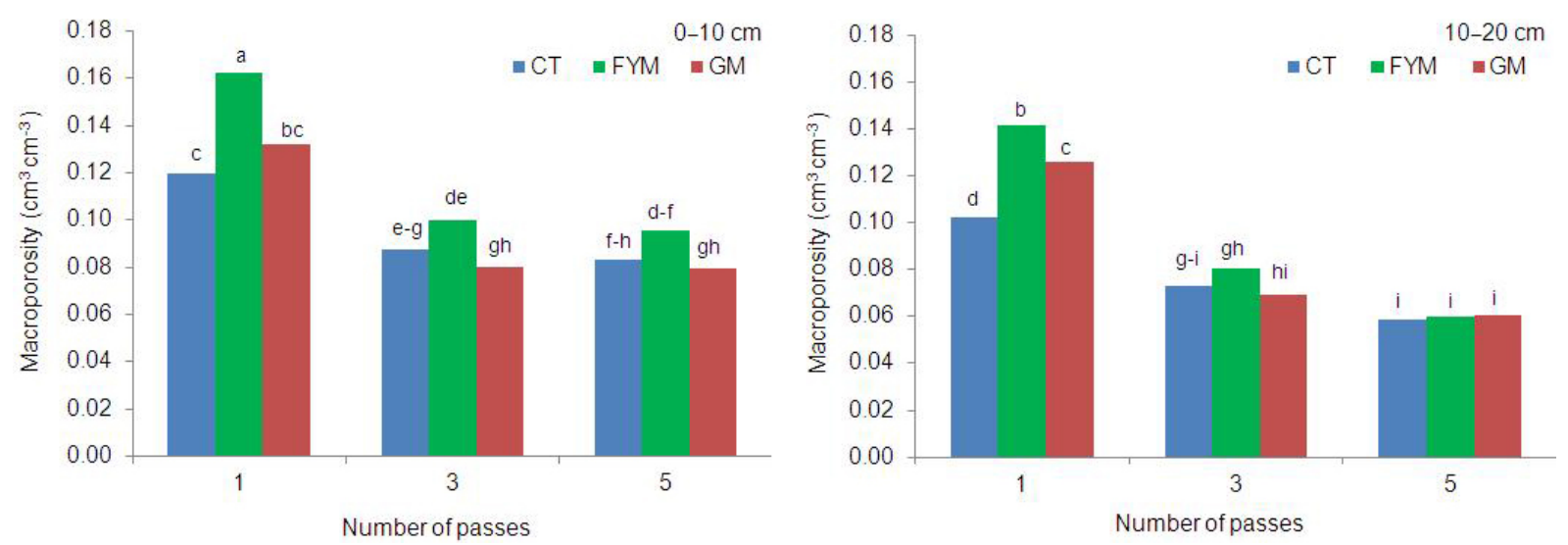

Figure 5. Number of passes and soil depth-dependent macroporosity changes induced by organic matter treatments (passing $\times$ depth, depth $\times$ treatment, passing $\times$ treatment; $P<0.01$ ). Different letters written above the columns indicate the difference in the treatment means at $P<0.05$.

improving bulk density for plant growth is related to the magnitude and quality of organic residues (Aksakal et al., 2016). Green manure, which is largely decomposed by leaving a smaller amount of organic matter, has a limited influence on soil physical attributes (Sauerbeck, 1982). Since FYM is more stable than the GM in terms of decomposition resistance, more organic compounds accumulated in soils (Table 2) treated with FYM. This in fact mediated the formation of aggregates resistant to soil traffic and therefore minimum bulk density was obtained in FYM plots. The main effect of soil depth irrespective of number of passes and organic matter addition was significant (Table 3). Surface layer had a smaller bulk density. The minimum bulk density $\left(1.25 \mathrm{~g} \mathrm{~cm}^{-3}\right)$ was obtained at $0-10 \mathrm{~cm}$ depth for one pass in FYM treatments, whereas the maximum bulk density $\left(1.61 \mathrm{~g} \mathrm{~cm}^{-3}\right)$ was recorded at $10-20 \mathrm{~cm}$ depth in the CT treatment with five passes (Fig. 2). The depth of soil compaction in the soil profile is dependent on the axle load, soil moisture content, tyre size, contact pressure, traffic density, and soil organic matter content attributes such as aggregation, aggregate stability, porosity, etc. (Hamza and Anderson, 2005). The greater the axle load and the wetter the soil is, the deeper the soil consolidates in the soil profile. Since in our case these two dependents were constant, the effects of organic matter treatments are rather apparent. The stronger structures induced by a larger amount and decompositionresistant organic substances scattered the force to a larger area, which minimised the compaction-induced bulk density differences in FYM-treated plots at any given pass number. At any steady state condition, in terms of organic matter addition, each treatment may be regarded as at fixed conditions. However, with a differing number of passes for each treatment, as in our case, the increasing traffic density resulted in increases in the bulk density deeper in the profile (Fig. 2). Parras-Alcantra et al. (2015) similarly reported that organic farming compared to conventional tillage significantly improved soil organic carbon stocks of soil, which resulted in a decrease in soil bulk density in the soil profile as deep as 
$76.1 \mathrm{~cm}$. Conversely, organic matter loss from conversion of forest soil to agricultural lands has made soil progressively bulkier for vertisols and ultisols in the last 20 years (Bruun et al., 2015), which in turn explains the significance of organic matter in managing bulk density.

\subsection{Porosity}

The main effects of organic matter incorporation, depth, and number of passes on porosity were significant (Table 3). The effects of treatments, in relation to soil depth and field traffic density, on porosity in descending order were FYM $>$ GM $>$ CT. The main overall effect of depth on total porosity was detrimental at $10-20 \mathrm{~cm}$ depth where a significant decrease was observed. The initial average $\left(0.565 \mathrm{~cm}^{3} \mathrm{~cm}^{-3}\right)$ of total porosity calculated from Table 2 showed a detrimental decrease down to 0.418 and $0.441 \mathrm{~cm}^{3} \mathrm{~cm}^{-3}$ after five and three passes (Table 3). From all plots considered, the maximum and minimum values of total porosity were 0.53 and $0.39 \mathrm{~cm}^{3} \mathrm{~cm}^{-3}$ respectively (Fig. 3). The effects of organic matter treatments, depth, and field traffic density on microporosity were statistically significant (Table 3). Microporosity and total porosity parameters similarly responded to organic matter treatments. The volume of micropores was significantly higher in surface layer than the one observed at $10-20 \mathrm{~cm}$ (Table 3). Maximum microporosity $\left(0.38 \mathrm{~cm}^{3} \mathrm{~cm}^{-3}\right)$ was recorded in the FYM treatment at $0-10 \mathrm{~cm}$ depth with three passes, whereas the minimum $\left(0.32 \mathrm{~cm}^{3} \mathrm{~cm}^{-3}\right)$ was determined in the CT treatment in the surface layer $(0-10 \mathrm{~cm})$ with five passes (Fig. 4). There was an increase in the microporosity of the control plot after one pass compared to its initial porosity, whereas a decrease was recorded for annual FYM- and GM-incorporated plots. After three passes were done, microporosity increased in all treatments including the control. The initial microporosity value and the value after five passes were nearly the same in the CT treatment but they dropped below even the initial porosity for FYM and GM treatments. Although the organic matter incorporation was only implemented for 4 years, the enhancement was recorded for porosity parameters. The enhancement induced by organic matter amendments in longterm studies at various locations was even more astonishing and is similar to our findings. For example, Rasool et al. (2008) and Arthur et al. (2013) reported increases in total porosity and water retention, which are related to pore nature of soil, with an increase in organic matter content depending on agricultural practices or organic matter amendments. FYM and GM, to a relatively smaller extent, promote total and microporosity in the current study. Organic matter application promotes the development of better soil structure by binding the soil particles with polysaccharides and bacterial exudates, which results in decreased bulk density and hence porosity (Bhatia and Shukla, 1982). As the level of soil compaction increased, the amount of water held in high matric potentials decreased, whereas the magnitude of water held at low matric potentials increased (Gupta et al., 1989) due to conversion of some macropores into micropores from compression stress. Similarly, Seker and Isildar (2000) reported an increase in the plant pore volume for holding plantavailable water after four passes. The descending order of the treatments was FYM $>\mathrm{GM}>\mathrm{CT}$ for both of the depths and each treatment, and as pointed out by Celik et al. (2004), microporosity increased with organic matter amendments.

Macroporosity, which is critical for soil aeration and soil water circulation, was changed as a function of soil depth, field traffic density, and organic matter amendments (Table 3). The main effect of organic matter was FYM $>$ GM $>$ CT in descending order. In this study, organic matter amendments significantly improved macroporosity $(P<0.01)$. However, field traffic at three and five passes (Table 3 ) reduced the macropore volume below the critical level of $0.1 \mathrm{~cm}^{3} \mathrm{~cm}^{-3}$ (Hakansson and Lipiec, 2000) and covered the effects of organic amendments. The maximum macroporosity $\left(0.16 \mathrm{~cm}^{3} \mathrm{~cm}^{-3}\right)$ was observed at $0-10 \mathrm{~cm}$ depth of the FYM treatment at one pass, whereas the minimum was recorded for the CT treatment at $10-20 \mathrm{~cm}$ depth at five passes (Fig. 5).

Enhancement of soil structure traits by reduction of aggregate wettability (Zhang and Hartge, 1992) and enhancement of strength of aggregate stability by incorporation of organic matter partially eliminated the effects of field traffic on macroporosity after 4 consecutive years of FYM and GM application. The organic-matter-bound ambiguity was attributed to type of organic matter, $\mathrm{C} / \mathrm{N}$ ratio, and the degree of resistance to decomposition. Readily decomposable soil organic matter was reported to be more relevant than total organic matter in mechanical characterisation of the soil (Ball et al., 2000). For example, the less-humified organic matter, such as green manure, was reported to highly efficiently increase aggregate porosity (Zhang, 1994). However, this effect was not found to be durable and resistant to field traffic as compared to the effects of FYM in the current study. Since the overall tendency of GM to increase soil organic matter is much less than the tendency of FYM, which is more stable and resistant to microbial decay, such behaviour is likely in soils that are poor in organic matter.

\section{Conclusions}

The effect of field traffic density on soil compaction was found to be dependent on addition and type of organic matter treatment. The overall effects of organic matter treatments on penetration resistance and bulk density irrespective of soil depth were in descending order CT $>$ GM $>$ FYM, whereas it was FYM $>$ GM $>$ CT for total and microporosity. Macroporosity appeared to be higher at minimum field traffic for the FYM treatment in the surface layer. It can be concluded that the use of organic matter enhances soil conditions by influencing the soil water holding and circulation characteristics, 
aeration, penetration resistance, and bulk density, which has implications for plant root growth.

\section{Data availability}

The data of this article can be found in the Supplement.

\section{The Supplement related to this article is available online at doi:10.5194/se-8-189-2017-supplement.}

Competing interests. The authors declare that they have no conflict of interest.

Edited by: P. Pereira

Reviewed by: two anonymous referees

\section{References}

Aggelides, S. M. and Londra, P. A.: Effects of compost produced from town wastes and sewage sludge on the physical properties of a loamy and a clay soil, Bioresource Technol., 71, 253-259, 2000.

Aksakal, E. L., Oztas, T., and Ozgul, M.: Time-dependent changes in distribution patterns of soil bulk density and penetration resistance in a rangeland under overgrazing, Turk. J. Agric. For., 35, 195-204, 2011.

Aksakal, E. L., Angin, I., and Oztas, T.: Effects of diatomite on soil physical properties, Catena, 88, 1-5, 2012.

Aksakal, E. L., Sari, S., and Angin, I.: Effects of vermicompost application on soil aggregation and certain physical properties, Land Degrad. Dev., 27, 983-995, 2016.

Aksakal, E. L.: Soil compaction and its importance for agriculture, Ataturk Univ., J. Fac. Agric., 35, 247-252, 2004.

Alagoz, Z., Yilmaz, E., and Okturen, F.: Effects of organic material addition on some physical and chemical properties of soils, Akdeniz Univ., J. Fac. Agric., 19, 245-254, 2006.

Al-Dousari, A. M., Misak, R., and Shahid, S.: Soil compaction and sealing in Al Salmi Area, Western Kuwait, Land Degrad. Dev., 11, 401-418, 2000.

Arslan, S.: An Alternative Method for Preventing Soil Compaction: Controlled Traffic, KSU, J. Sci. Eng., 9, 135-141, 2006.

Arthur, E., Schjonning, P., Moldrup, P., Tuller, M., and de Jonge, L. W.: Density and permeability of a loess soil: Long-term organic matter effect and the response to compressive stress, Geoderma, 193-194, 236-245, 2013.

Ball, B. C., Campbell, D. J., and Hunter, E. A.: Soil compactibility in relation to physical and organic properties at 156 sites in UK, Soil Till. Res., 57, 83-91, 2000.

Barbero-Sierra, C., Marques, M. J., Ruiz-Pérez, M., Escadafal, R., and Exbrayat, W.: How is Desertification Research Addressed in Spain? Land Versus Soil Approaches, Land Degrad. Dev., 26, 423-432, 2015.
Bhatia, K. S. and Shukla, K. K.: Effect of continuous application of fertilizers and manure on some physical properties of eroded alluvial soil, J. Indian Soc. Soil Sci., 30, 33-36, 1982.

Blake, G. R. and Hartge, K. H.: Bulk density, in: Methods of Soil Analysis, Part 1, Physical and Mineralogical Methods, edited by: Klute, A., Agr. Monogr., ASA and SSSA, Madison WI, USA, 9, 363-375, 1986.

Blanco-Moure, N., Gracia, R., Bielsa, A. C., and López M. V.: Soil organic matter fractions as affected by tillage and soil texture under semiarid Mediterranean conditions, Soil Till. Res., 155, 381-389, 2016.

Bouyoucos, G. J.: Hydrometer method improved for making particle size analyses of soils, Agron. J., 54, 464-465, 1962.

Bruun, T. B., Elberling, B., de Neergaard, A., and Magid, J.: Organic carbon dynamics in different soil types after conversion of forest to agriculture, Land Degrad. Dev., 26, 272-283, 2015.

Burt, R. (Ed.): Soil Survey Laboratory Methods Manual, Soil Survey Investigations Rep. 42, version 4.0, USDA-NRCS, 2004.

Busscher, W. J. and Sojka, R. E.: Enhancement of subsoiling effect on soil strength by conservation tillage, Transac. Am. Soc. Agric. Engin., 30, 888-892, 1987.

Carman, K.: Tractor forward volocity and tine load effects on soil strength, J. Terramechanics, 31, 11-20, 1994.

Carter, M. R.: Soil quality for sustainable land management: organic matter and aggregation interactions that maintain soil functions, Agron. J., 94, 38-47, 2002.

Celik, I., Ortas, I., and Kilic, S.: Effects of compost, mycorrhiza, manure and fertilizer on some physical properties of a Chromoxerert soil, Soil Till. Res., 78, 59-67, 2004.

Celik, I., Gunal, H., Budak, M., and Akpinar, C.: Effects of longterm organic and mineral fertilizers on bulk density and penetration resistance in semi-arid Mediterranean soil conditions, Geoderma, 160, 236-243, 2010.

Cerdà, A.: Aggregate stability against water forces under different climates on agriculture land and scrubland in southern Bolivia, Soil Till. Res., 57, 159-166, 2000.

Chaudhari, P. R., Ahire, V., Ahire, D. V., Chkravarty, V. D., and Maity, S.: Soil bulk density as related to soil texture, organic matter content and available total nutrients of Coimbatore soil, Int. J Sci. Res. Pub., 3, 1-8, 2013.

Cochrane, H. R. and Aylmore, L. A. G.: The effects of plant roots on soil structure, in: Proceedings of 3rd Triennial Conference "Soils 94”, 207-212, 1994.

Czyz, E. A. and Dexter, A. R.: Estimation of the density of the clayorganic complexes in soil, Int. Agrophys., 30, 19-23, 2016.

Danielson, R. E. and Sutherland, P. L.: Porosity, in: Methods of Soil Analysis, Part 1, Physical and Mineralogical Methods, 2nd Edn., edited by: Klute, A., Agron. Monogr. 9., ASA and SSSA, Madison WI., USA, 443-461, 1986.

De Moraes, M. T., Debiasi, H., Carlesso, R., Franchini, J. C., and Da Silva, V. R.: Critical limits of soil penetration resistance in a rhodic eutrudox, R. Bras. Ci. Solo, 38, 288-298, 2014.

De Oliveira, S. P., de Lacerda, N. B., Blum, S. C., Escobar, M. E. O., and de Oliveira, T. S.: Organic carbon and nitrogen stocks in soils of northeastern Brazil converted to irrigated agriculture, Land Degrad. Dev., 26, 9-21, 2015.

Erbach, D.: Farm equipment and soil compaction, ASAE Paper No: 860730, 1986. 
Gelaw, A. M., Singh, B. R., and Lal R.: Organic carbon and nitrogen associated with soil aggregates and particle sizes under different land uses in Tigray, Northern Ethiopia, Land Degrad. Dev., 26, 690-700, 2015.

Gulser, C. and Candemir, F.: Changes in penetration resistance of a clay field with organic waste applications, Eurasian J. Soil Sci., 1, 16-21, 2012.

Gupta, S. C., Sharma, P. P., and DeFranchi, S. A.; Compaction effects on soil structure, in: Advances in Agronomy, edited by: Brady, N. C., 42, 311-338, 1989.

Hakansson, I. and Lipiec, J.: A review of the usefulness of relative bulk density values in studies of soil structure and compaction, Soil Till. Res., 53, 71-85, 2000.

Hamza, M. A. and Anderson, W. K.: Responses soil properties and grain yields to deep ripping and gypsum application in a compacted loamy sand soil contrasted with a sandy clay loam soil in Western Australia, Aust. J. Agr. Res., 54, 273-282, 2003.

Hamza, M. A. and Anderson, W. K.: Soil compaction in cropping systems: a review of the nature, causes and possible solutions, Soil Till. Res., 82, 121-145, 2005.

Hamza, M. A. and Anderson, W. K.: Combinations of ripping depth and tine spacing for compacted sandy and clayey soils, Soil Till. Res., 99, 213-220, 2008.

Haynes, R. J. and Naidu, R.: Influence of lime, fertilizer and manure applications on soil organic matter content and soil physical conditions: a review, Nutr. Cyc. Agroecosys., 51, 123-137, 1998.

Kacar, B.: Soil Analysis, Nobel publications, Ankara, 2009 (in Turkish).

Kaleeem Abbasi, M., Mahmood Tahir, M., Sabir, N., and Khurshid, M.: Impact of the addition of different plant residues on nitrogen mineralization-immobilization turnover and carbon content of a soil incubated under laboratory conditions, Solid Earth, 6, 197205, doi:10.5194/se-6-197-2015, 2015.

Keesstra, S. D., Bouma, J., Wallinga, J., Tittonell, P., Smith, P., Cerdà, A., Montanarella, L., Quinton, J. N., Pachepsky, Y., van der Putten, W. H., Bardgett, R. D., Moolenaar, S., Mol, G., Jansen, B., and Fresco, L. O.: The significance of soils and soil science towards realization of the United Nations Sustainable Development Goals, SOIL, 2, 111-128, doi:10.5194/soil-2-1112016, 2016.

Kozlowski, T. T.: Soil Compaction and Growth of Woody Plants, Scand. J. Forest Res., 14, 596-619, 1999.

Mamman, E., Ohu, J. O., and Crowther, T.: Effect of soil compaction and organic matter on the early growth of maize (Zea mays) in a vertisol, Int. Agrophys., 21, 367-375, 2007.

McGarry, D.: Tillage and soil compaction, in: Conservation Agriculture, edited by: Garcia-Torres, L., Benites, J., Martínez-Vilela, A., and Holgado-Cabrera, A., Kluwer Academic Publishers, 307-316, 2003.

Minitab: Minitab 16 Statistical Software (30 days trial version), Minitab Inc., State College, Pennsylvania, USA, 2010.

Muñoz-Rojas, M., Jordán, A., Zavala, L. M., De la Rosa D., AbdElmabod, S. K., and Anaya-Romero, M.: Impact of land use and land cover changes on organic carbon stocks in mediterranean soils (1956-2007), Land Degrad. Dev., 26, 168-179, 2015.

Munsuz, N.: Soil Mechanics and Technology, Publications of Ankara Univ. Faculty of Agriculture, 922, 260, Ankara, 1985 (in Turkish).
Ni, J., Luo, D. H., Xia, J., Zhang, Z. H., and Hu, G.: Vegetation in karst terrain of southwestern China allocates more biomass to roots, Solid Earth, 6, 799-810, doi:10.5194/se-6-799-2015, 2015.

Novara, A., Gristina, L., Guaitoli, F., Santoro, A., and Cerdà, A.: Managing soil nitrate with cover crops and buffer strips in $\mathrm{Si}-$ cilian vineyards, Solid Earth, 4, 255-262, doi:10.5194/se-4-2552013, 2013.

Ola, A., Dodd, I. C., and Quinton, J. N.: Can we manipulate root system architecture to control soil erosion?, SOIL, 1, 603-612, doi:10.5194/soil-1-603-2015, 2015.

Parras-Alcántara, L., Díaz-Jaimes, L., and Lozano-García, B.: Organic farming affects $\mathrm{C}$ and $\mathrm{N}$ in soils under olive groves in mediterranean areas, Land Degrad. Dev., 26, 800-806, 2015.

Patel, S. K. and Mani, I.: Effect of multiple passes of tractor with varying normal load on subsoil compaction, J. Terramechanics, 48, 277-284, 2011.

Peng, F., Quangang, Y., Xue, X., Guo, J., and Wang, T.: Effects of rodent-induced land degradation on ecosystem carbon fluxes in an alpine meadow in the Qinghai-Tibet Plateau, China, Solid Earth, 6, 303-310, doi:10.5194/se-6-303-2015, 2015.

Pulido, M., Schnabel, S., Contador, J. F. L., Lozano-Parra, J., and González, F.: The impact of heavy grazing on soil quality and pasture production in rangelands of SW Spain, Land Degrad. Dev., doi:10.1002/ldr.2501, 2016.

Rasool, R., Kukal, S. S., and Hira, G. S.: Soil organic carbon and physical properties as affected by long-term application of FYM and inorganic fertilizers in maize-wheat system, Soil Till. Res., 101, 31-36, 2008.

Sauerbeck, D. R.: Influence of crop rotation, manurial treatment and soil tillage on the organic matter content of German soils, in: Soil Degradation, edited by: Boels, D., Davies, D. B., and Johnston, A. E., Proceedings of the EEC Seminar held in Wageningen, Rotterdam, A A Balkema, Netherlands, 163-179, 1982.

Seker, C. and Isildar, A. A.: Effects of wheel traffic porosity and compaction of soil profile, Turk. J. Agric. For., 24, 71-77, 2000.

Shaw, E. A., Denef, K., Milano de Tomasel, C., Cotrufo, M. F., and Wall, D. H.: Fire affects root decomposition, soil food web structure, and carbon flow in tallgrass prairie, SOIL, 2, 199-210, doi:10.5194/soil-2-199-2016, 2016.

Sparovek, G., Lambais, M. R., Silva, A. P., and Tormena, C. A.: Earthworm (Pontoscolex corethrurus) and organic matter effects on the reclamation of an eroded oxisol, Pedobiologia, 43, 698704, 1999.

Thomas, G. W., Haszler, G. R., and Blevins, R. I.: The effect of organic matter and tillage on maximum compactibility of soils using the proctor test, Soil Sci., 161, 502-508, 1996.

USDA: Soil Survey Manual, Soil Survey Division Staff, Washington, DC, USA, 1993.

USDA-NRCS: Soil Compaction, available at: http://www.nrcs. usda.gov/Internet/FSE_DOCUMENTS/stelprdb1187272.pdf, (last access: 27 May 2016), 2012.

Uzumcu, E.: The effects of farm manure and green manure applications on soil aggregation, Suleyman Demirel University Graduate School of Natural and Applied Sciences Department of Soil Science and Plant Nutrition, MS Thesis, 2016 (in Turkish).

Xin, X., Zhang, J., Zhu, A., and Zhang, C.: Effects of long-term (23 years) mineral fertilizer and compost application on physical 
properties of fluvo-aquic soil in the North China Plain, Soil Till. Res., 156, 166-172, 2016.

Wang, T., Xue, X., Zhou, L., and Guo, J.: Combating Aeolian Desertification in Northern China, Land Degrad. Dev., 26, 118-132, 2015.

Yan, X. and Cai, Y.L.: Multi-Scale Anthropogenic Driving Forces of Karst Rocky Desertification in Southwest China, Land Degrad. Dev., 26, 193-200, 2015.
Zhang, H. and Hartge, K. H.: Effect of differently humified organic matter on the aggregate stability by reducing aggregate wettability, Z. Pflanz. Bodenkunde, 155, 143-149, 1992.

Zhang, H.: Organic matter incorporation affects mechanical properties of soil aggregates, Soil Till. Res., 31, 263-275, 1994. 